\title{
Protecting Agriculture: The Legal Basis of Regulatory Action in Florida
}

\author{
Regina M. Fegan, Assistant General Counsel, Florida Department of Environmental Protection, Tallahassee 32399; \\ Michael T. Olexa, Professor, Agricultural Law and Director, Agricultural Law Center, University of Florida Institute \\ of Food and Agricultural Sciences, Gainesville 32611; and Robert J. McGovern, Professor, Plant Pathology De- \\ partment and Director, Plant Medicine Program, University of Florida Institute of Food and Agricultural Sciences, \\ Gainesville 32611
}

\begin{abstract}
Fegan, R. M., Olexa, M. T., and McGovern, R. J. 2004. Protecting agriculture: The legal basis of regulatory action in Florida. Plant Dis. 88:1040-1043.

The Division of Plant Industry of the Department of Agriculture and Consumer Services of Florida is empowered to protect the state's agriculture from both introduction and intrastate movement of pests. This responsibility is shared by similar regulatory agencies of the federal government and other states. The legal basis of such regulatory action, police power and eminent domain, is reviewed. The regulatory processes by the State of Florida of two important citrus pests, the burrowing nematode and Asiatic citrus canker, are presented. It was concluded that Florida's regulatory power to take property is of great importance to the agricultural industry and to Florida's economy. This power must be exercised within the constitutional limitation that "no person shall be deprived of life, liberty, or property without due processes of law." However, the imminence of an emergency may justify state action without a prior hearing or just compensation of valueless items.
\end{abstract}

Additional keywords: Radopholus similis, spreading decline, Xanthomonas axonopodis pv. citri

Protection of agriculture through prevention of both introduction and intrastate movement of pests is an essential responsibility of certain state and federal regulatory agencies. Since the tragic events of September 11, 2001, this mandate has assumed an even greater importance because of the potential threat to crops posed by the deliberate introduction of pests by bioterrorists.

The State of Florida, as other states in the United States, has a duty to protect its agricultural interests from pests (arthropods, pathogens, noxious plants, etc.). The power to exercise protective measures originates from the police power inherent in Florida's sovereignty and requires no constitutional recognition (7). The use of police power to protect Florida's agricultural interests is delegated by the Legislature to the Director of the Division of Plant Industry within the De-

Corresponding author: M. T. Olexa

E-mail: olexa@fred.ifas.ufl.edu

This research was supported by the Florida Agricultural Experiment Station, and approved for publication as Journal Series No. R-10275.

Accepted for publication 16 April 2004.

Publication no. D-2004-0624-01S

(c) 2004 The American Phytopathological Society partment of Agriculture and Consumer Services (14).

The objective of this report is to clarify the legal authority underlying regulatory action to protect agriculture from pests by reviewing relevant statutes and legal decisions. The scope of police power to take private property for a public purpose and the elements of due process that limit that power are presented. In addition, two different cases in Florida, relating to pests of citrus, are used to demonstrate how the courts determine what process is due.

\section{Power to Take Private Property for a Public Purpose}

\section{Police Power and Eminent Domain}

The power of the State of Florida to take private property for a public purpose is subdivided into categories based upon the government's purpose for taking the property. The subdivisions are the police power and the power of eminent domain.

Police power. Florida exercises police power when it takes property to protect "public safety, public welfare, public morals, or public health (26)." The State's power to take property for such reasons is based on the fundamental principle of "sic utere tuo ut alienum non laedas" which means that no one shall use their property to wrong or injure another (25). The term "police power" is sometimes used to only describe activities that do not require compensation. However, the exercise of police power may require compensation. The Florida Supreme Court stated that "it is a well settled proposition that a regulation or statute may meet the standards necessary for exercise of the police power but still result in a taking $(8,9,20,25)$."

Eminent domain. Florida exercises eminent domain when it takes property for a public use. Article 10, section 6 of the Florida Constitution limits the power of eminent domain by stating "no private property shall be taken except for a public purpose and with full compensation (11)."

It should be noted that it is difficult to discern the boundary line between the actions that are compensable under the police power and compensable under eminent domain (2). The distinction is that eminent domain transfers property to a public agency for public use, while police power is the regulation of use that results in an impairment of value or destruction (25). In other words, if a regulation creates a public benefit it is more likely an exercise of eminent domain, and if a regulation prevents a public harm it is more likely an exercise of police power $(8,20)$.

\section{Due Process Limitations \\ on Police Power}

The Florida Constitution limits Florida's authority to take property under its police power. Article I, section 9 states that "No person shall be deprived of life, liberty, or property without due processes of law (10)."

In State Plant Board v. Smith, the court defines due process as "conformity with the natural and inherent principles of justice for the protection of individual rights (25)." The court further states that due process "requires that no one be condemned in person or property without the opportunity to be heard" and "forbids the taking of property without just compensation (25)."

Conformity with the natural and inherent principles of justice. Florida's police power is "confined to those acts which may reasonably be construed as being expedient" for the protection of public welfare (25). A valid exercise of police 
power cannot be arbitrary or capricious (4). The analysis of whether an exercise of police power was reasonable examines the knowledge present at the time the action was taken (4). The current level of knowledge is incorporated into subsequent decisions, thus demonstrating that the police power is "extensive, elastic, and constantly evolving to meet new and increasing demands (1)."

Notice and opportunity to be heard. Due process requires notice and a full and fair opportunity to be heard $(6,22,25)$. However, due process does not necessarily require a hearing before the exercise of police power $(21,25)$. In many instances, the exercise of police power results in the summary destruction of property without a prior hearing (25). The summary destruction is valid if there is a compelling public interest to justify the action, such as an immediate threat to public health, safety, or welfare (25).

Just compensation. Whether the regulatory action of a public body amounts to a taking must be determined from the facts of each case $(8,9)$. In such cases, the trial judge is the trier of all factual and legal issues, except for the amount of compensation $(8,9)$.

Some of the factors ... [the trial judge considers to determine if the police power resulted in a taking] are:

1. Whether there is a physical invasion of the property.

2. The degree to which there is a diminution in value of the property. Or stated another way, whether the regulation precludes all economically reasonable use of the property.

3 . Whether the regulation confers a public benefit or prevents a public harm.

4. Whether the regulation promotes the health, safety, welfare, or morals of the public.

5. Whether the regulation is arbitrarily and capriciously applied.

6. The extent to which the regulation curtails investment-backed expectations (20).

The decision of the trial judge is presumed correct and not disturbed on appeal if the decision is supported by competent, substantial evidence $(8,9,20)$.

The courts closely scrutinize police actions that destroy property. The Florida Supreme Court stated that the absolute destruction of property is an extreme exercise of police power and is justified only within the narrowest limits of actual necessity, unless the state chooses to pay compensation $(5,9)$.

However, the state is not compelled to compensate for property that is valueless, incapable of any lawful use, and a source of public danger $(5,8,25)$. This provision fits nicely into the scheme if rephrased to say that the state is obligated to compensate for the property, but that the amount of compensation is a nullity because the property is without value. The court, in State Plant Board v. Smith, lists as examples "diseased cattle, unwholesome meats, decayed fruit or fish, infected clothing, obscene books or pictures, or buildings in the path of a conflagration (25)."

\section{What Process Is Due When Agricultural Crops Are Destroyed: The Florida Example}

The following two cases demonstrate how the facts of a case play a key role in determining what process is due when agricultural crops are destroyed through the exercise of police power authority. Both sets of cases deal with diseases that affect citrus trees, spreading decline and citrus canker.

The first type of case deals with a disease known as spreading decline. Spreading decline is caused by the burrowing nematode, Radopholus similis (27). This nematode damages the feeder roots of citrus trees, and over time, the root system deteriorates, causing the tree's productivity to decline (27). The trees are rendered commercially unprofitable under ordinary market conditions. The burrowing nematode spreads slowly among trees in a grove at a rate of about two rows of trees per year from the infection front (3).

The second type of case deals with a disease known as Asiatic citrus canker. Citrus canker is caused by the bacterium Xanthomonas axonopodis pv. citri $(17,18)$. The bacterium causes defoliation, dieback, blemished fruit, reduced fruit quality, and premature fruit drop $(17,18)$. Unlike spreading decline, citrus canker spreads rapidly by wind-driven rain, flooding, air currents, insects, birds, human movement within the groves, and movement of infected plants and seedlings $(17,18)$. Symptoms may manifest as early as 7 days after inoculation under optimum conditions (20 to $\left.30^{\circ} \mathrm{C}\right)(17,18)$. Symptoms may take 60 days or more to appear under less than optimum conditions (16).

\section{Spreading Decline}

In 1957, the Florida Supreme Court first addressed the issue of spreading decline in Corneal v. State Plant Board (5). The case was brought against the State Plant Board to enjoin it from removing all of the citrus trees affected by the nematode and the first four trees past the last visibly affected tree (5). The grove in question had 703 citrus trees, 16 of which were actually affected (5). The Board's program called for the destruction of 197 trees (5).

Note that the court did not consider the burrowing nematode an immediate threat. There was a hearing before, rather than after, the actual destruction (5).

The issue of just compensation was decided in two parts. The first part was whether the regulation calling for the destruction of the diseased trees was valid (5). The court answered this in the affirma- tive because the trees were valueless and required no compensation (5). The second part was whether the regulation calling for the destruction of healthy but suspect trees was valid (5). The court answered this in the affirmative but required the state to give just compensation (5). The action is justified under the police power because the program is necessary to protect trees on neighboring property (5). However, healthy but suspect trees are not without value (5). Therefore, the destruction of healthy but suspect trees is a police power that results in a taking (5). In sum, the affected party was granted a hearing prior to destruction, was not compensated for the infected trees, and was compensated for the healthy but suspect trees.

The control of spreading decline falls under the scope of police powers. Therefore, the state is authorized to destroy both diseased and healthy but suspect trees. However, since the dissemination of spreading decline is slow, due process required a hearing before the exercise of power. The state does not have to give compensation for diseased trees because they are without value but does have to give compensation for the destruction of healthy but suspect trees because, although infected, they do retain some value.

\section{Citrus Canker}

Citrus canker was first discovered in Florida in 1912, and the ensuing eradication program was considered successful and ended in 1933 (23). From 1986 on, there have been many new detections of citrus canker. In the mid-1980s, the Asiatic strain of $X$. axonopodis pv. citri was detected in Florida $(17,18)$. This strain is highly aggressive and has the potential to devastate the citrus industry and Florida's economy (17).

The court reacted to the detection of Asiatic citrus canker by permitting the exercise of summary destruction in Nordmann v. Florida Department of Agriculture and Consumer Services and Denney $v$. Conner $(6,22)$. In both cases, citrus growers acquired trees from nurseries where citrus canker was detected $(6,22)$. The growers' trees appeared healthy but were suspected of infection $(6,22)$. The Department of Agriculture, without a prior hearing, ordered the destruction of these healthy but suspect trees $(6,22)$. The growers contended that suspect trees did not pose an imminent threat $(6,22)$. The court concluded that the suspect trees constituted an imminent threat $(6,22)$, due to the fact that citrus canker may be transmitted by both natural (wind and rain) and artificial (man and machinery) means and that it may remain symptomless for two or more months before manifesting signs of the disease (17-19).

The agency was "factually explicit and persuasive concerning the existence of a genuine emergency," thus abrogating the 
need for a prior hearing (6). The court did not address the issue of compensation in either case $(6,22)$.

In Department of Agriculture and Consumer Services v. Mid-Florida Growers, Inc., the court addressed "whether the state, pursuant to its police power, has the constitutional authority to destroy healthy but suspect citrus plants without compensation (8)." Here, the court answered the question in the negative (8). The court noted that the destruction conferred a benefit to the citrus industry and Florida's economy as a whole, rather than merely preventing a public harm (8). The conferring of a benefit coupled with the trial court's finding that the trees were, in fact, healthy led the court to conclude that the destruction was a taking without the requisite compensation (8). The court stated that a mere suspicion of infection is insufficient to consider the trees valueless (8). The state was required to pay full and just compensation for the destruction of healthy but suspect trees (8).

Department of Agriculture and Consumer Services v. Polk added an interesting twist to the previous certified question (9). The court upheld the finding by the trial judge, in that trees located within a 38.1-m (125-ft) buffer of those exhibiting symptoms had no market value (9). Trees within the 38.1-m buffer zone were considered "incapable of any lawful use, it is of no value, and it is a source of public danger (9)." The destruction of these trees did not require compensation (9).

Until recently, the scientific basis for eradication of citrus canker was research conducted in Argentina indicating that the pathogen can be spread up to $38.1 \mathrm{~m}$ by wind-blown rain (24). Subsequently, the Department of Agriculture determined that the 38.1-m buffer was insufficient to reduce citrus canker in a Florida setting $(17,18)$. This research, known as "the Gottwald study," determined that the "125$\mathrm{ft}$ rule" was inadequate because it only captured about 30 to $41 \%$ of infection spreading from a diseased tree $(17,18)$. This study ultimately concluded that a $579-\mathrm{m} \quad(1,900-\mathrm{ft})$ buffer was needed $(17,18)$. The Department of Agriculture was granted authority to remove trees within the new 579-m buffer zone by Florida Statute Section 581.184 (12).

The enlargement of the buffer zone from $38.1 \mathrm{~m}$ to $579 \mathrm{~m}$ reignited due process challenges. In Florida Dept. Of Agriculture and Consumer Services v. Haire, the court was asked to determine the constitutionality of Florida Statute Section 581.184 (15). It had been previously decided that nursery trees within $38.1 \mathrm{~m}$ of an infected tree had a sufficient risk of infection to justify summary destruction by the Department of Agriculture (15). Here, the issue was whether the summary destruction of residential trees within $579 \mathrm{~m}$ of an infected tree was a valid exercise of police power
(15). Residential owners claimed that the commissioned study was not based upon reliable science and therefore was outside of the scope of police power (15). In response, the court noted that "legislatures are not limited to acting only where there is scientific certainty (15)." Here, the legislature reasonably relied on a "peer reviewed and published" study and recommendations of the technical advisory board (15). Courts are not permitted to substitute their own scientific judgment if the legislature's decision was "neither arbitrary nor capricious and bears a reasonable relationship to the goal of canker eradication (15)." This statutory challenge is currently on appeal to the Florida Supreme Court (15).

What follows is a review of procedures authorized by Florida Statute 581.184 (12). These are the procedures the Florida Department of Agriculture and Consumer Services must follow if the Florida $\mathrm{Su}-$ preme Court affirms the decision in Haire (15). Florida Statute 581.184 requires that owners be notified of the impending destruction by order (15). The owner has the option to ask for a stay of destruction in an appellate court where the only issues are whether the tree itself is infected and whether the tree is within $579 \mathrm{~m}$ of an infected tree (15). Since the disease spreads at a fast rate, the court held that the state had adequate reason to not conduct a full hearing prior to eradicating an "imminent danger (15)." The owners may opt for a hearing after destruction (15). The hearing determines if the destruction of exposed but healthy trees constitutes a taking and, if so, the amount of compensation required (15). These hearings will determine if trees within the 579-m buffer zone require compensation beyond the $\$ 100$ provided by the statute (15).

The control of citrus canker, like spreading decline, falls under the scope of police powers. However, the due process requirements are different for citrus canker. Citrus canker, unlike spreading decline, poses an imminent danger, thus justifying the lack of a full hearing prior to destruction. The state does not have to give compensation for canker-infected trees because they are without value. However, unlike spreading decline, healthy but suspect trees may or may not be subject to compensation. Since citrus canker spreads at such a rapid rate and an infected tree takes a while to manifest symptoms, the courts have ruled that trees within $38.1 \mathrm{~m}$ of an infected tree are without value.

\section{Conclusion}

Florida's use of the police power to take property for protecting the "public safety, public welfare, $\ldots$ or public health" is of great importance to the agricultural industry and to Florida's economy (26). This power must be exercised within the constitutional limitation that "no person shall be deprived of life, liberty, or property without due processes of law (10)." However, the imminence of an emergency may justify the state action without a prior hearing or just compensation of valueless items.

One must keep in mind that the constitutional limitations are just that-limitations. Statutes may extend benefits beyond the limitations of the constitution. Many statutory schemes allow for compensation of both diseased and nondiseased trees. For instance, although courts have held that diseased trees are without value, Florida Statute 581.1845 compensates homeowners for the destruction of their trees in the amount of $\$ 100$ per tree (13). The state, by compensating for diseased trees, extends a benefit beyond what is required by the Florida Constitution.

However, as evidenced by the litigation, many property owners disagree with the scope of police power utilized in the citrus canker statute. Currently, the courts held that the legislation is not arbitrary or capricious and is based on reasonable evidence. Remedies for future disagreement now appear to be in the legislative arena rather than in the courts.

\section{LITERATURE CITED}

1. 16A American Jurisprudence 2d Constitutional Law Section 315 (1998).

2. 16A American Jurisprudence $2 \mathrm{~d}$ Constitutional Law Section 318 (1998).

3. Browning H. W., McGovern, R. J., Jackson, L. K., Calvert, D. V., and Wardowski, W. F. 1995 Florida Citrus Diagnostic Guide. Florida Science Source, Lake Alfred, FL.

4. Conner v. Reed Bros., Inc., 567 Southern 2d 515, 517 (Fla. 2nd DCA 1990).

5. Corneal v. State Plant Board, 95 Southern 2d 1, 2-4 (Fla. 1957).

6. Denney v. Conner, 462 Southern 2d 534, 534536 (Fla. 1st DCA 1985).

7. Department of Agriculture and Consumer Services v. Bonanno, 568 Southern 2d 24, 29 (Fla. 1990).

8. Department of Agriculture and Consumer Services v. Mid-Florida Growers, Inc., 521 Southern 2d 101, 101-4 (Fla. 1988), certiorari denied, 488 U.S. 870, 109 S.Ct. 180, 102 L.Ed.2d 149 (1988)

9. Department of Agriculture and Consumer Services v. Polk, 568 Southern 2d 35, 39-40 (Fla. 1990).

10. Fla. Const. Art. I, Section 9.

11. Fla. Const. Art. X, Section 6.

12. Fla. Stat. Section 581.184 (2002).

13. Fla. Stat. Section 581.1845 (2002).

14. Fla. Stat. Section 581.031(7).

15. Florida Dept. of Agriculture and Consumer Services v. Haire, 836 So.2d 1040, 1050-4 (Fla. 4th DCA 2003) certiorari granted, 842 Southern 2d 844 (Fla. 2003).

16. Gottwald, T. R., and Graham, J. H. 1992. A device for precise and nondisruptive stomatal inoculation of leaf tissue with bacterial pathogens. Phytopathology 82:930-935.

17. Gottwald, T. R., Graham, J. H., and Schubert, T. S. 2002. Citrus canker: The pathogen and its impact. Online. Plant Health Progress doi:10.1094/PHP-2002-0812-01-RV.

18. Gottwald, T. R., Sun, X., Riley, T., Graham, J. H., Ferrandino, F., and Taylor, E. L. 2002. Geo-referenced spatiotemporal analysis of the urban citrus canker epidemic in Florida. Phytopathology 92:361-377.

19. Graham, J. H., Gottwald, T. R., Cubero, J., and 
D. S. Anchor. 2004. Xanthomonas axonopodis pv. citri: Factors affecting successful eradication of citrus canker. Online. Molecular Plant Pathology doi:10.1046/j.1364-3703.2004. 00197.x.

20. Graham v. Estuary Properties, Inc., 399 Southern 2d 1374, 1380-1 (Fla. 1981) certiorari denied, 454 U.S. 1083, 102 S.Ct. 640, 70 L.Ed.2d 618 (1981).

21. Louis K. Liggett Co. v. Amos, 104 Fla. 609, 141 Southern 153, 156 (Fla. 1932)
22. Nordmann v. Florida Department of Agriculture and Consumer Services, 473 Southern 2d 278, 278-280 (Fla. 5th DCA 1985).

23. Schoulties, C. L., Civerolo, E. L., Miller, J. W., Stall, R. E., Krass, C. J., Poe, S. R., and DuCharme, E. P. 1987. Citrus canker in Florida. Plant Dis. 71:388-395.

24. Stall, R. E., Miller, J. W., Marco, G. M., and de Echenique, B. I. C. 1980. Population dynamics of Xanthomonas citri causing cancrosis of citrus in Argentina. Proc. Fla. State Hortic. Soc. 93:10-14.

25. State Plant Board v. Smith, 110 Southern 2d 401, 404-7 (Fla. 1959).

26. Sweat v. Turpentine \& Rosin Factors, Inc., 15 Southern 2d 267, 270 (Fla. 1943).

27. Timmer, L. W., Garnsey, S. M., and Graham, J. H., eds. 2000. Compendium of Citrus Diseases. 2nd ed. American Phytopathology Society, St. Paul, MN. 